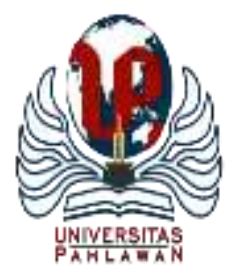

\title{
JURNALBASICEDU
}

Volume 6 Nomor 1 Tahun 2022 Halaman 1285 - 1296

Research \& Learningin Elementary Education

https://jbasic.org/index.php/basicedu

\section{Learning Progression Guru Sekolah Dasar dalam Pengembangan Konten Soal Asesmen Kompetensi Minimum (AKM)}

\author{
Tyas Deviana ${ }^{1}$, Dian Fitri Nur Aini ${ }^{2 凶}$ \\ Pendidikan Guru Sekolah Dasar, Universitas Muhammadiyah Malang, Indonesia ${ }^{1,2}$ \\ E-mail: tyasdefiana@umm.ac.id ${ }^{1}$, dianfitri@umm.ac.id ${ }^{2}$
}

\begin{abstract}
Abstrak
Penelitian ini bertujuan untuk memberikan gambaran mendalam tentang learning progression guru Sekolah Dasar dalam menyusun soal Asesmen Kompetensi Minimum (AKM). Dalam pelaksanaan Asesmen Kompetensi Minimum (AKM), learning progression (kemajuan pembelajaran) berkaitan dengan proses kesinambungan antara jenjang dan kemampuan berpikir. Kesinambungan pada Asesmen Kompetensi Minimum (AKM) dapat dilihat dari aspek konten teks, level kognitif yang diukur, dan indikator yang temuat dalam soal Asesmen Kompetensi Minimum (AKM). Penelitian ini menggunakan pendekatan kualtitatif dengan metode deskriptif. Subyek penelitian adalah guru SD, Kepala Sekolah dan siswa SD pada Gugus V Kecamatan Tumpang Kabupaten Malang. Tahapan penelitian dimulai dari pengumpulan data, reduksi data, penyajian data dan penarikan kesimpulan. Hasil penelitian menunjukan bahwa pada proses learning progression soal yang dikembangkan dibuat sesuai dengan cakupan serta keluasan pada masing-masing level. Cakupan permasalahan pada level 1 mencakup permasalahan di rumah dan di sekolah, kemudian pada level 2 cakupan lebih luas lagi yaitu pada cakupan lingkungan sekitar dan kearifan lokal daerah, dan pada level 3 cakupan teks yang dikembangkan lebih luas lagi meliputi nasional dan permasalahan-permasalahan global.
\end{abstract}

Kata Kunci: AKM, Learning Progression, Sekolah Dasar.

\section{Abstract}

The aims of this study is to provide an in-depth description of the learning progression of elementary school teachers in preparing Asesmen Kompetensi Minimum (AKM). In the implementation of Asesmen Kompetensi Minimum (AKM), learning progression is related to the continuity process between levels and thinking skills. The continuity of the Minimum Competency Assessment (AKM) can be seen from the aspect of the text content, the cognitive level measured, and the indicators contained in the Asesmen Kompetensi Minimum (AKM). This study uses a qualitative approach with a descriptive method. The research subjects were elementary school teachers, principals and elementary students in Gugus V, Tumpang District, Malang Regency. The research stages start from data collection, data reduction, data presentation and conclusion drawing. The results showed that in the learning progression process the questions developed were made in accordance with the scope and breadth of each level. The scope of the problems at level 1 includes problems at home and at school, then at level 2 the coverage is wider, namely the scope of the surrounding environment and local wisdom, and at level 3 the scope of the texts developed is wider covering national and global issues.

Keywords: AKM, Learning Progression, Primary School

Copyright (c) 2022 Tyas Deviana, Dian Fitri Nur Aini

$\triangle$ Corresponding author :

Email : dianfitri@umm.ac.id

ISSN 2580-3735 (Media Cetak)

DOI $\quad$ : https://doi.org/10.31004/basicedu.v6i1.2095

ISSN 2580-1147 (Media Online) 


\section{PENDAHULUAN}

Program penilaian mutu pada setiap Lembaga Pendidikan pada jenjang dasar dan menengah yang saat ini sedang digunakan disebut dengan istilah Asesmen Nasional. Penilaian mutu satuan Pendidikan ditinjau berdasarkan kemampuan mendasar yang disajikan dalam bentuk hasil belajar peserta didik antara lain kemampuan literasi, numerasi dan karakter. Selain itu penilaian juga dilakukan pada kualitas proses pembelajaran yang dilakukan dan iklim satuan Pendidikan yang mendukung pembelajaran tersebut. Asesmen Nasional berfungsi sebagai alat untuk mengevaluasi mutu sistem serta sebagai sumber informasi untuk memetakan sistem sebagai hasil tindak lanjut dari evaluasi yang telah dilakukan untuk menentukan perancangan program Pendidikan selanjutnya (Perdana, 2021). Data terkait mutu satuan Pendidikan diperoleh dari tiga instrumen utama, yaitu Asesmen Kompetensi Minimum (AKM), Survei Karakter, dan Survei Lingkungan Belajar.

Asesmen Nasional mengukur berbagai aspek dalam pembelajaran, salah satunya adalah aspek kognitif. Pada aspek kognitif, Asesmen Nasional mengukur dua kemampuan mendasar yang harus dikuasai peserta didik, yaitu literasi membaca dan literasi numerasi yang termuat dalam Asesmen Kompetensi Minimum (AKM). Kedua kemampuan mendasar baik literasi membaca atau literasi numerasi dikembangkan secara lintas mata pelajaran (Tohir, 2019). Pengembangan kemampuan literasi dan numerasi dapat dilakukan pada seluruh mata pelajaran di Sekolah Dasar, yaitu Bahasa Indonesia, IPA, IPS, Matematika, dan PKn.

Asesmen literasi membaca dan numerasi pada AKM dapat ditinjau dari 3 komponen (aspek) yaitu: konten, proses kognitif, serta konteks. Bagan berikut menjelaskan rincian komponen AKM literasi membaca serta numerasi.

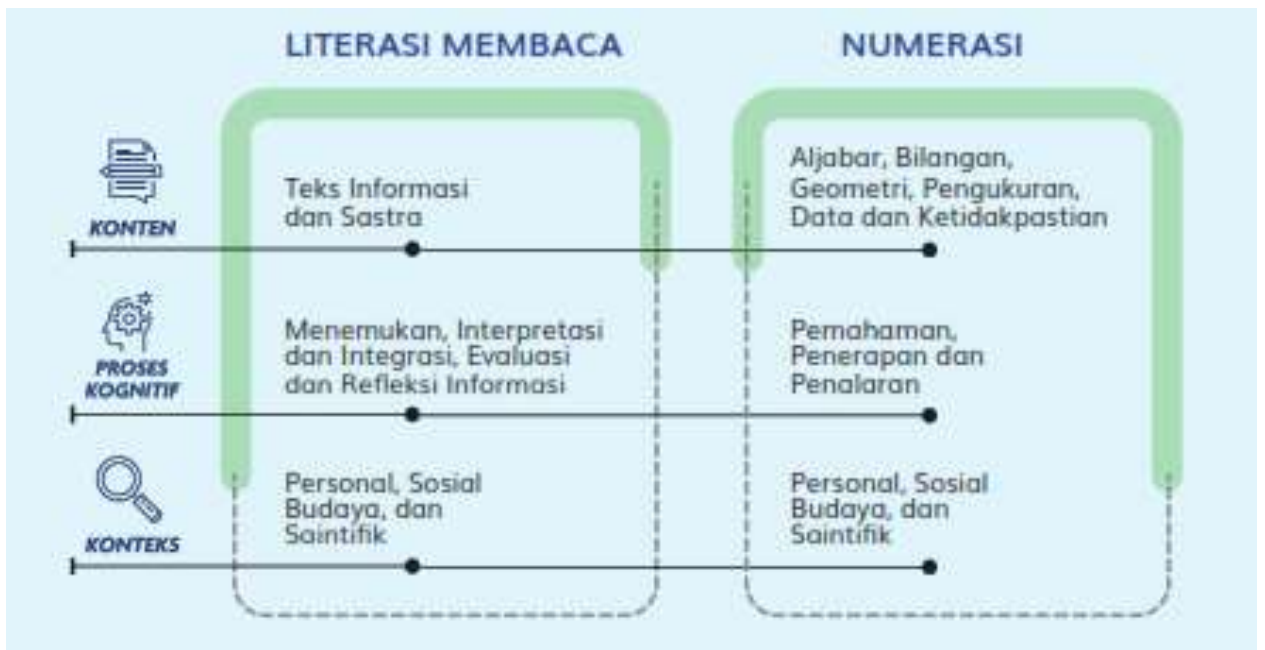

Gambar Bagan Komponen Asesmen Literasi Membaca dan Numerasi

Penilaian kemampuan kognitif peserta didik dapat dilakukan dengan menggunakan instrumen yang disebut dengan Asesmen Kompetensi Minimum (AKM). Asesmen Kompetensi Minimum (AKM) merupakan penilaian kemampuan mendasar peserta didik pada jenjang pendidikan tertentu. Penilaian pada kemampuan mendasar peserta didik dilakukan pada konten yang bersifat esensial serta berkelanjutan pada lintas kelas maupun jenjang (Pangesti, 2018). Istilah minimum dapat diartikan bahwa konten yang diukur tidak pada seluruh konten yang termuat dalam kurikulum namun difokuskan pada konten yang esensial.

Konten esensial yang diukur dari Asesmen Kompetensi Minimum terdiri dari literasi membaca dan literasi numerasi. Kemampuan literasi membaca dan literasi numerasi merupakan kemampuan dasar yang perlu dimiliki oleh peserta didik pada jenjang tertentu. Kemampuan literasi membaca menurut National 
1287 Learning Progression Guru Sekolah Dasar dalam Pengembangan Konten Soal Asesmen Kompetensi Minimum (AKM) - Tyas Deviana, Dian Fitri Nur Aini

DOI: https://doi.org/10.31004/basicedu.v6i1.2095

Institut for Literacy mencakup kemampuan membaca, menulis, berbicara, dan memecahkan masalah sesuai jenjang pendidikanya. Dapat dijelaskan bahwa kemampuan literasi membaca tidak sebatas hanya mampu membaca. Sedangkan literasi numerasi mencakup kemampuan mengaplikasikan konsep hitungan dalam suatu konteks, baik abstrak maupun nyata yang diaplikasikan dalam kehisupan sehari-hari. Kemampuan literasi membaca dan literasi numerasi sesuai dengan kecakapan abad ke-21 yang mengharuskan peserta didik mampu mengikuti perkembangan dan tantangan zaman.

Dengan menguasai kecakapan abad ke-21, peserta didik akan mampu berinovasi dan memiliki keterampilan belajar (Papp et al., 2014). Selain itu, peserta didik juga diharuskan mampu menggunakan serta memanfaatkan teknologi dan media informasi yang saat ini sedang berkembang. Selanjutnya, peserta didik diharpkan mampu bekerja dan betahan dengan memanfaatkan kecakapan hidup (life skill) yang dimilikinya. Untuk mewujudkan berbagai kemampuan dasar peserta didik pada berbagai jenjang, Kementerian Pendidikan dan Kebudayaan melalui Pusat Asesmen dan Pembelajaran menetapkan Asesmen Kompetensi Minimum (AKM) dalam bentuk desain pengembangan soal AKM yang dapat dimodifikasi serta disesuaikan lingkungan peserta didik oleh guru.

Desain pengembangan soal Asesmen Kompetensi Minimum (AKM) berfungsi sebagai kerangka sekaligus sebagai acuan untuk proses implementasinya dalam pembelajaran. Desain pengembangan soal Asesmen Kompetensi Minimum disusun untuk mempermudah dan memberikan referensi kepada guru dan sekolah dalam mengembangkan soal-soal Asesmen Kompetensi Minimum yang memuat kemampuan abad-21 seningga memfasilitasi peserta didik untuk berinovasi dan berpikir kritis. Dengan adanya Asesmen Kompetensi Minimum yang termuat dalam soal-soal Asesmen Kompetensi Minimum (AKM) peserta didik diharapkan dapat meningkatkan tahapan belajar secara berkesinambungan.

Learning progression (kemajuan pembelajaran) merupakan urutan pembelajaaran secara berkesinambungan pada peserta didik di berbagai tahap perkembangan, usia dan tingkat kelas (Stevens et al., 2013). Tahapan pembelajaran yang dilakukan oleh peserta didik pada berbagai jenjang mencakup tiga aspek yaitu karakteristik, keluasan dan kedalaman materi pembelajaran pada setiap jenjang Pendidikan. Cakupan ruang lingkup materi dirumuskan berdasarkan perkembangan peserta didik sehingga tidak menimbulkan miskonsepsi dan berjalan sejajar sesuai dengan tahapan perkembangan serta kemampuannya (Duschl et al., 2011).

Dalam pelaksanaan Asesmen Kompetensi Minimum (AKM), learning progression (kemajuan pembelajaran) berkaitan dengan proses kesinambungan antara jenjang dan kemampuan berpikir. Kesinambungan pada Asesmen Kompetensi Minimum (AKM) dapat dilihat dari aspek konten teks, level kognitif yang diukur, dan indikator yang temuat dalam soal Asesmen Kompetensi Minimum (AKM). Terdapat perbedaan mulai dari isi dan konteks bacaan, level kognitif dan indikator soal dari berbagai tingkatan level. Di Sekolah Dasar, level kognitif Asesmen Kompetensi Minimum dimulai dari level 1 (untuk kelas 1-2), level 2 (kelas 3-4) dan level 3 (untuk kelas 5-6).

Pengembangan soal Asesmen Kompetensi Minimum (AKM) secara berkesinambungan pada berbagai level dilakukan oleh guru pada satuan Pendidikan. Guru diharuskan memiliki kemampuan dalam menyusun soal Asesmen Kompetensi Minimum (AKM). Hal ini dikarenakan soal pada AKM lebih menekankan pada soal yang membutuhkan kemampuan analisis dan bernalar kritis, serta mampu mengembangkan kemampuan berfikir divergen pada peserta didik. Bentuk soal pada AKM juga bervariasi tidak hanya pilihan ganda seperti halnya pada soal UN. Adapun bentuk soal AKM terdiri dari pilihan ganda, pilihan ganda kompleks, menjodohkan, isian singkat dan uraian.

AKM mengukur kompetensi kecakapan hidup yang merupakan hasil belajar peserta didik lintas beragam mata pelajaran. Oleh karena itu,keberhasilan di AKM tidak melalui proses drilling soal-soal (Sofanudin, 2020). Satuan pendidikan diharapkan mewujudkan proses pembelajaran yang mendorong terbangunnya kompetensi serta karakter peserta didik. Satuan pendidikan diharapkan aktif mengikuti simulasi 
1288 Learning Progression Guru Sekolah Dasar dalam Pengembangan Konten Soal Asesmen Kompetensi Minimum (AKM) - Tyas Deviana, Dian Fitri Nur Aini

DOI: https://doi.org/10.31004/basicedu.v6i1.2095

sebagai upaya menyiapkan peserta didik menghadapi AKM. Setiap guru dapat memetakan kemampuan peserta didiknya menggunakan instrument AKM kelas.

Sosialisasi dan pelatihan terkait Asesmen Kompetensi Minimum di Sekolah Dasar sudah mulai dilakukan pada beberapa wilayah di Indonesia baik secara daring maupun luring. Pelatihan dilaukan secara bertahap dari wilayah satu ke wilayah yang lain. Implementasi Asesmen Kompetensi Minimum (AKM) pada Sekolah Dasar saat ini masih dilakukan pada kelas 5. Namun, peserta pelatihan Asesmen Kompetensi Minimum (AKM) harus diikuti oleh semua guru pada setiap jenjang Pendidikan.

Berdasarkan hasil wawancara kepada salah satu guru di Kelompok Kerja Guru (KKG) Gugus V Kec. Tumpang Kabupaten Malang menyatakan bahwa 75\% guru kelas atas pada KKG Gugus V Kec. Tumpang sudah mengikuti pelatihan dan sosialisasi AKM secara daring maupun luring. Pelatihan secara daring dilakukan oleh Kemendikbud secara bergiliran mulai guru kelas 1 sampai kelas 5. Pelatihan secara daring diikuti oleh guru-guru yang mampu mengoperasikan perangkat komputer. Untuk memfasilitasi guru senior yang belum terlalu mahir dalam mengoperasikan komputer, telah dilakukan pelatihan Asesmen Kompetensi Minimum (AKM) oleh Universitas dalam bentuk kegiatan pengabdian pada masyarakat. Pendampingan penyusunan soal Asesmen Kompetensi Minimum lebih intens dilakukan untuk menghasilkan soal AKM agar sesuai kriteria yang telah ditetapkan oleh Kemendikbud.

Sebagian besar guru pada KKG Gugus V Kecamatan Tumpang Kabupaten Malang yang telah mengikuti pelatihan AKM sudah menyusun soal Asesmen Kompetensi Minimum (AKM). Penggunaan variasi soal-soal AKM juga telah dilakukan. Bentuk soal yang dahulu hanya menggunakan pilihan ganda dan essay, saat ini dikembangkan lebih variatif pada bentuk soal pilihan ganda kompleks, menjodohkan serta isian singkat dan uraian. Pengembangan soal AKM yang memuat berbagai muatan pembelajaran juga sudah dilakukan dengan menggabungkan 2 sampai 3 muatan pada satu soal AKM yang disajikan. Teks yang disajikan sudah menerapkan berbagai teks yang harus termuat dalam soal AKM yaitu teks fiksi dan teks informasi. Namun, dari berbagai proses pengembangan sampai implementasi soal AKM belum dilakukan proses validasi soal-soal AKM yang telah disusun.

Dari paparan yang dijabarkan terkait soal Asesmen Kompetensi Minimum (AKM) yang telah dikembangkan oleh guru pada KKG Gugus V Kecamatan Tumpang Kabupaten Malang, perlu dilakukan telaah lebih mendalam terkait kompetensi guru dalam menyesuaikan soal-soal AKM dengan konteks learning progression peserta didik di Sekolah Dasar pada Gugus V Kecamatan Tumpang Kabupaten Malang. Learning progression dapat dilihat dari aspek karakteristik, keluasan materi dan kedalaman materi pembelajaran. Tapi pada penelitian ini fokus pada analisis aspek karakteristik atau konten soal AKM yang dikembangkan oleh guru.

\section{METODE PENELITIAN}

Penelitian ini menggunakan pendekatan penelitian kualitatif dengan menerapkan metode deskripstif. Metode deskriptif digunakan karena menghasilkan data faktual yang diolah secara kuantitatif berdasarkan informasi statistik, dan data kualitatif yang dihasilkan berdasarkan hasil-hasil penelitian (Moleong, 2021). Penelitian kualitatif dilaksanakan untuk membangun pengetahuan melalui pemahaman dan penemuan secara mendalam (Creswell \& Poth, 2016). Penelitian tentang kompetensi guru dalam penyusunan soal Asesmen Kompetensi Minimum (AKM) bertujuan untuk mendeskripsikan kompetensi guru dalam penyusunan soal Asesmen Kompetensi Minimum (AKM) pada Sekolah Dasar yang disesuaikan dengan konteks Learning Progression untuk peserta didik.. Subyek penelitian adalah guru-guru pada Kelompok Kerja Guru (KKG) di Gugus V Kecamatan Tumpang Kabupaten Malang berjumlah 12 orang, Kepala Sekolah dan siswa kelas V SDN Tumpang VI Kabupaten Malang. 
1289 Learning Progression Guru Sekolah Dasar dalam Pengembangan Konten Soal Asesmen Kompetensi Minimum (AKM) - Tyas Deviana, Dian Fitri Nur Aini

DOI: https://doi.org/10.31004/basicedu.v6i1.2095

Data dikumpulkan dengan menggunakan wawancara, observasi dan dokumentasi dari hasil produk soalsoal Asesmen Kompetensi Minimum yang telah dikembangkan oleh guru Sekolah Dasar di Gugus V Kecamatan tumpang Kabupaten Malang yang dilakukan selama 4 bulan. Wawancara dilakukan terkait proses penyusunan soal Asesmen Kompetensi Minimum (AKM) pada guru di Sekolah Dasar pada Gugus V Kecamatan Tumpang Kecamatan Malang. Observasi dilakukan pada saat proses implementasi soal Asesmen Kompetensi Minimum (AKM) di SD Tumpang VI Kabupaten Malang. Dokumen dalam bentuk soal-soal Asesmen Kompetensi Minimum dari semua guru pada Gugus V Kecamatan Tumpang Kabupaten Malang dikumpulkan kemudian dianalisis dan dilakukan teknik triangulasi sumber dan triangulasi teknik untuk mengkonfirmasi keabsahan datanya.

Prosedur pelaksanaan penelitian diawali dengan melakukan observasi awal di lapangan untuk menggali data awal terkait proses penyusunan soal Asesmen Kompetensi Minimim oleh guru Sekolah Dasar di Gugus V Kecamatan Tumpang Kabupaten Malang. Selain itu, untuk mendapatkan data yang berkaitan, juga dilakukan wawancara dan FGD dengan tim guru Sekolah Dasar di Gugus V Kecamatan Tumpang Kabupaten Malang.

Pada tahapan selanjutnya, data yang telah diperoleh kemudian dilakukan analisis untuk mendapatkan penafsiran data sesuai dengan konteks penelitian. Selain itu dilakukan juga reduksi pada data-data yang kurang relevan dengan topik yang menjadi fokus penelitian. Setelah proses analisis data dan reduksi data selesai dilakukan, dilakukan tahapan verifikasi dengan menggunakan teknik triangulasi sumber dan triangulasi Teknik. Pada triangulasi sumber, data dikonfirmasi keabsahannya kepada kepala sekolah dan siswa kelas V SD di Gugus V Kecamatan Tumpang Kabupaten Malang. Selanjutnya dilakukan kesimpulan-kesimpulan sebagai hasil generalisasi topik penelitian.

\section{HASIL DAN PEMBAHASAN}

Perubahan sistem penilaian pendidikan dasar dan menengah yang semula menggunakan Ujian Nasional (UN) sekarang menjadi Asesmen Nasional (AN). Adanya perubahan tersebut tidak hanya sebatas pada istilah yang digunakan, namun juga termasuk konten yang di dalamnya. Salah satu aspek yang dinilai pada AN yaitu Asesmen Kompetensi Minimum (AKM). AKM merupakan salah satu instrumen dari Asesmen Nasional (AN) yang akan dilaksanakan pada tahun 2021 untuk jenjang Sekolah Dasar. AKM akan menilai mutu suatu lembaga pendidikan pada aspek kognitif peserta didik.

Asesmen Kompetensi Minimum (AKM) dilakukan untuk mengukur literasi membaca dan numerasi peserta didik. Pengertian minimum untuk menunjukkan literasi membaca dan numerasi merupakan kompetensi yang setidak-tidaknya harus dimiliki untuk seseorang dapat berfungsi secara produktif dalam kehidupan. Konten yang diukur bersifat esensial serta berkelanjutan lintas kelas maupun jenjang. Tidak semua konten pada kurikulum diujikan. Istilah minimum juga memaknai bahwa konten yang diukur bukanlah seluruh konten pada kurikulum namun konten yang esensial (Pangesti, 2018).

Adanya perbedaan konten dan konteks pada AKM dari UN, menjadikan guru harus beradaptasi dengan perubahan yang terjadi. Bentuk adaptasi guru yang bisa dilakukan yaitu guru dapat mengembangkan soal AKM kelas. Pengembangan soal AKM bertujuan untuk menghasilkan penilaian yang dibutuhkan dalam Asesmen Nasional ini. Pengembangan soal AKM harus menghasilkan soal-soal yang bersifat kontekstual, menggunakan berbagai bentuk tipe soal yang bervariasi, mengukur kompetensi pemecahan masalah, dan merangsang peserta didik untuk berpikir kritis. Hal ini sesuai dengan pendapat Resti (2020) yang menjelaskan bahwa AKM dirancang berfungsi sebagai pendukung terlaksananya pembelajaran inovatif yang berorientasi pada pengembangan kemampuan bernalar dan tidak hanya sebatas pada hafalan.

Learning progression menjadi bagian yang tidak boleh dilupakan dalam pengembangan soal AKM. Guru harus memahami learning progression dalam pengembangan soal AKM ini. Learning progresssion ini disebut juga kemajuan pembelajaran. Definisi dari learning progression merupakan 
adalah urutan prosedur pembelajaran yang berjalan berkesinambungan (Neumann et al., 2013). Hal ini sesuai dengan pendapat Wilson (2009) berpendapat bahwa learning progression mendeskripsikan perubahan yang terjadi antara keadaan awal suatu kejadian dan keadaan akhirnya.

Dalam konteks pelaksanaan AKM, learning progression berkaitan dengan kesinambungan antara satu jenjang kelas ke jenjang berikutnya (Sevian \& Talanquer, 2014). Kesinambungan ini mencakup aspek konten materi, level kognitif (kompetensi) yang diukur, dan indikator yang ditanyakan pada soal AKM. Soal AKM yang dikembangkan oleh guru harus melihat perkembangan kompetensi antar kelas dalam domain yang sama, level kognitif, dan indikator yang diukur dimulai dari kelas rendah (level 1) sampai level tertinggi di jenjang SD (level 3). Perbedaan itu tergambar dalam kompleksitas materi. Ada tiga aspek yang harus berkesinambungan pada learning progression dalam pengembangan AKM, yaitu aspek karakteristik, keluasan, dan kedalaman materi pembelajaran dalam setiap jenjang pendidikan (Ismail \& Zakiah, 2021). Selain itu, dalam asesmen kompetensi minimum memiliki variasi soal dalam penerapannya. Variasi pada soal AKM dimaksudkan agar peserta didik mampu mengerjakan soal dalam berbagai bentuk yang dihadirkan (Sari et al., 2021).

Berdasarkan hasil penelitian yang dilakukan oleh peneliti kepada guru SD kelas 1 sampai kelas 6 di Kelompok Kerja Guru (KKG) Gugus V Kecamatan Tumpang, diperoleh informasi terkait learning progression guru dalam mengembangkan soal AKM. Pengembangan soal AKM oleh guru, merupakan tindak lanjut dari adanya pendampingan pengembangan soal AKM. Learning progression guru dalam mengembangkan soal AKM dilihat melalui tiga aspek yang harus berkesinambungan, yaitu aspek karakteristik (konten), keluasan (proses kognitif), dan kedalaman (konteks) materi pembelajaran dalam setiap jenjang pendidikan SD. Berikut hasil penelitian terkait learning progression guru SD dalam mengembangkan soal AKM pada aspek karakteristik (konten).

Pengembangan soal AKM harus memperhatikan beberapa hal antara lain karakteristik materi pembelajaran yang ada pada tiap jenjang kelas (Rahmayanti \& Affandi, 2021). Soal AKM yang dikembangkan guru mengacu pada literasi membaca dan literasi numerasi yang merupakan kemampuan dasar yang harus dimiliki oleh peserta didik. Literasi membaca tidak hanya mengacu pada pembelajaran pada muatan Bahasa Indonesia saja. Literasi membaca tidak hanya sekedar lancar membaca teks namun harus dapat memahami isi teks yang dibaca. Tabel 1 berikut merupakan hasil wawancara dan observasi terkait learning progression guru SD dalam mengembangkan soal AKM literasi membaca yang mencakup karakteristik materi pembelajaran.

Tabel 1. Learning Progression Guru Pengembangan Soal AKM Literasi Membaca Aspek Karakteristik Materi Pembelajaran.

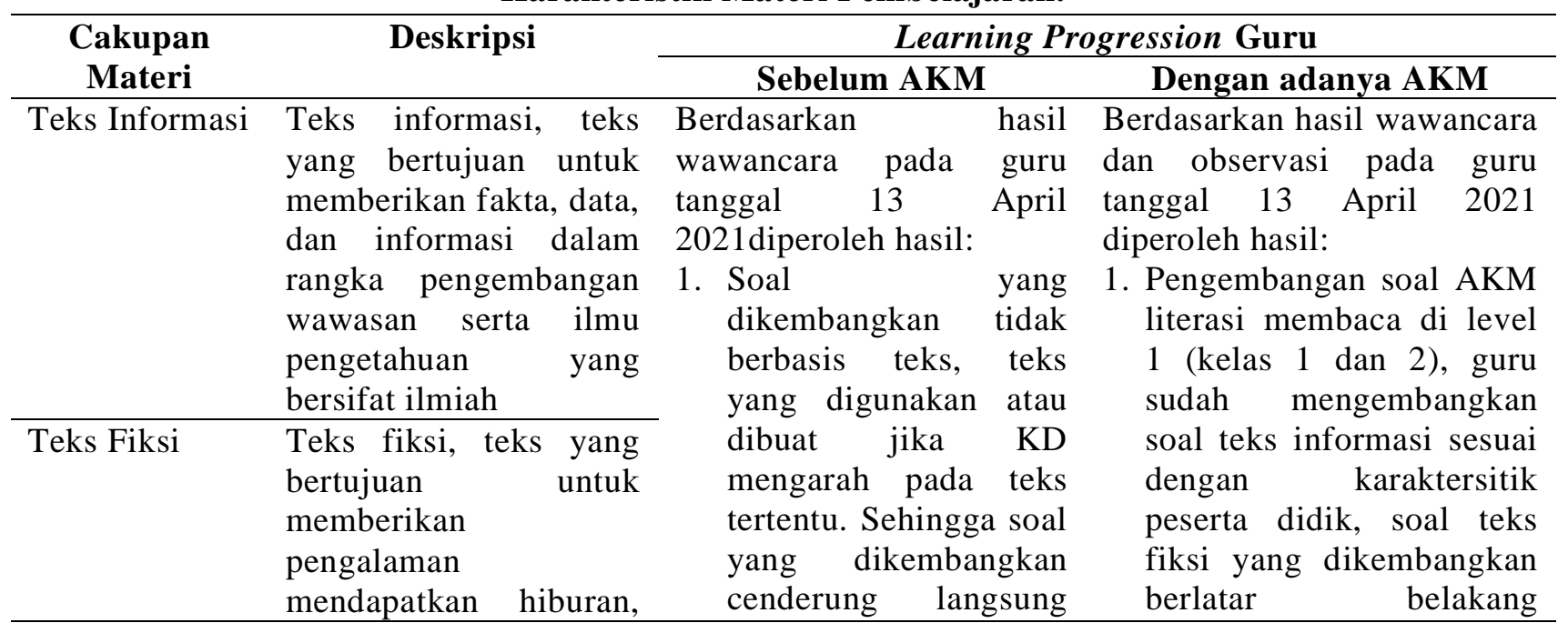


1291 Learning Progression Guru Sekolah Dasar dalam Pengembangan Konten Soal Asesmen Kompetensi Minimum (AKM) - Tyas Deviana, Dian Fitri Nur Aini

DOI: https://doi.org/10.31004/basicedu.v6i1.2095

\begin{tabular}{|c|c|c|c|}
\hline \multirow{3}{*}{$\begin{array}{c}\text { Cakupan } \\
\text { Materi }\end{array}$} & \multirow{2}{*}{$\begin{array}{l}\text { Deskripsi } \\
\text { menikmati cerita, dan } \\
\text { melakukan perenungan } \\
\text { kepada pembaca }\end{array}$} & \multicolumn{2}{|c|}{ Learning Progression Guru } \\
\hline & & Sebelum AKM & Dengan adanya AKM \\
\hline & $\begin{array}{l}\text { menikmati cerita, dan } \\
\text { melakukan perenungan } \\
\text { kepada pembaca }\end{array}$ & $\begin{array}{l}\text { menuju pada apa yang } \\
\text { ditanyakan, tanpa ada } \\
\text { stimulasi bacaan atau } \\
\text { permasalahan terlebih } \\
\text { dahulu. } \\
\text { 2. Teks yang } \\
\text { dikembangkan tidak } \\
\text { mengacu pada teks } \\
\text { informasi dan teks } \\
\text { fiksi } \\
\text { 3. Soal yang } \\
\text { dikembangkan kurang } \\
\text { variatif, hanya soal } \\
\text { dengan tipe pilihan } \\
\text { ganda dan uraian. } \\
\text { 4. Soal yang } \\
\text { dikembangkan belum } \\
\text { ditambahkan dengan } \\
\text { visual gambar yang } \\
\text { dapat membantu } \\
\text { pemahaman peserta } \\
\text { didik. } \\
\text { 5. Belum bentuk } \\
\text { mengintegrasikan } \\
\text { kearifan lokal daerah } \\
\text { sebagai bai bentuk } \\
\text { pengintegrasian } \\
\text { contextual learning. }\end{array}$ & 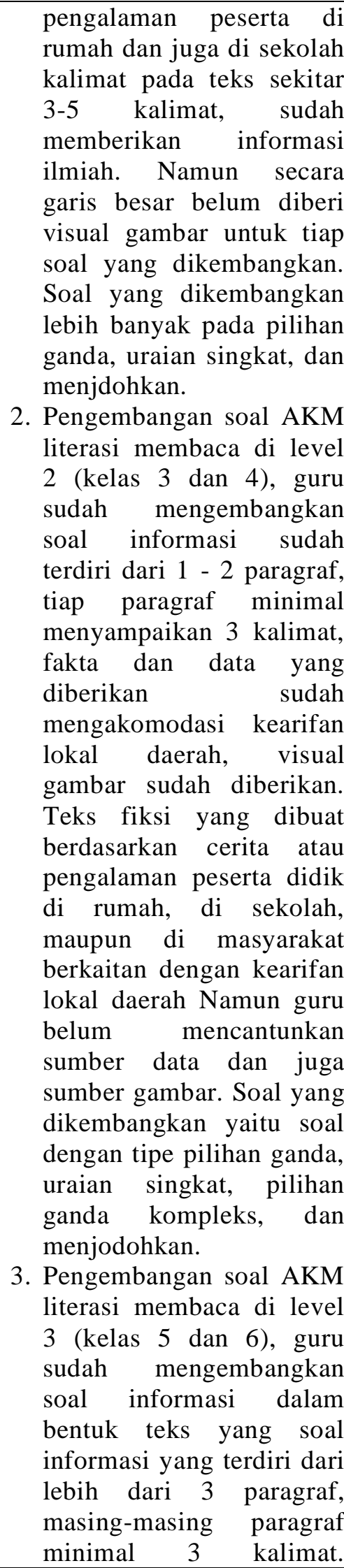 \\
\hline
\end{tabular}


1292 Learning Progression Guru Sekolah Dasar dalam Pengembangan Konten Soal Asesmen Kompetensi Minimum (AKM) - Tyas Deviana, Dian Fitri Nur Aini

DOI: https://doi.org/10.31004/basicedu.v6i1.2095

\begin{tabular}{|c|c|c|c|}
\hline \multirow{2}{*}{$\begin{array}{c}\text { Cakupan } \\
\text { Materi }\end{array}$} & \multirow{2}{*}{ Deskripsi } & \multicolumn{2}{|c|}{ Learning Progression Guru } \\
\hline & & Sebelum AKM & Dengan adanya AKM \\
\hline & & & $\begin{array}{l}\text { Menggunakan data dan } \\
\text { informasi sesuai dengan } \\
\text { kearifan lokal daerah dan } \\
\text { juga pada tingkat } \\
\text { nasional. Sumber data } \\
\text { sudah dituliskan, namun } \\
\text { untuk sumber gambar } \\
\text { perlu ditambahkan. Teks } \\
\text { fiksi yang dikembangkan } \\
\text { disesuaikan dengan cerita } \\
\text { dan pengalaman peserta } \\
\text { didik di rumah, sekolah, } \\
\text { masyarakat, kearifan lokal } \\
\text { daerah, sampai nasional } \\
\text { Soal yang dikembangkan } \\
\text { lebih bervariasi, meliputi } \\
\text { pilihan ganda, pilihan } \\
\text { ganda kompleks, uraian, } \\
\text { menjodohkan, dan uraian } \\
\text { singkat. }\end{array}$ \\
\hline
\end{tabular}

Berdasarkan analisis hasil penelitian learning progression guru dalam mengembangkan konten soal AKM literasi membaca di jenjang SD, diketahui bahwa teks yang dikembangkan sudah sesuai dengan ketentuan AKM yaitu teks informasi dan teks fiksi. Learning progression guru dalam membuat teks disesuaikan dengan tahap perkembangan peserta didik, hal ini terbukti dengan banyak kalimat dalam paragraph untuk level 1 (kelas 1 dan 2) terdiri dari 3 - 4 kalimat pendek, level 2 (kelas 3 dan 4) terdiri dari 2 - 3 paragraf, dan level 3 (kelas 5 dan 6) terdiri dari $3-4$ paragraf. Hal ini disimpulkan bahwa banyak kalimat dalam teks disesuaikan dengan tahap perkembangan peserta didik dengan banyak kalimat yang sedikit pada level rendah dan bertambah banyak untuk tiap levelnya dan AKM lebih mengarah pada pembelajaran yang berpusat pada guru. Pernyataan ini sesuai dengan pendapat Nehru (2019) yang menyebutkan bahwa pelaksanaan asesmen kompetensi minimum lebih mengarah pada student centered learning (SCL).

Learning progression guru dalam mengembangkan soal AKM literasi membaca untuk teks informasi sudah menggunakan data dan fakta yang teruji keabsahan datanya namun bisa ditambahkan dengan sumber data yang dicantumkan dengan jelas. Selain itu soal teks yang dikembangkan memiliki cakupan yang berbeda untuk tiap levelnya. Cakupan level AKM memiliki tiga level yaitu level 1, level 2 dan level 3 (Ahmad et al., 2021). Cakupan level 1 meliputi data dan cerita pengalaman di rumah dan di sekolah, teks level 2 meliputi data dan cerita pengalaman di rumah, di sekolah dan di masyarakat dengan mengintegrasikan kearifan lokal daerah, dan di level 3 meliputi data dan cerita pengalaman di rumah, di sekolah, di masyarakat dengan kearifan lokal daerah, sampai pada permasalahan nasional. Hal ini membuktikan bahwa learning progession guru dalam mengembangkan soal AKM literasi membaca mulai cakupan dari yang terdekat dengan peserta didik sampai pada cakupan yang lebih luas yaitu nasional. Pengembangan soal AKM literasi membaca dilakukan secara bertahap agar peserta didik mudah memahami soal AKM (Plummer \& Krajcik, 2010).

Soal AKM yang dikembangkan oleh guru tidak hanya literasi membaca, namun juga literasi numerasi. Literasi numerasi yang dimaksudkan pada Asesmen Kompetensi Minimum tidak memiliki makna yang sama dengan matematika (Sani, 2021). Walaupun keduanya berlandaskan pada pengetahuan 
1293 Learning Progression Guru Sekolah Dasar dalam Pengembangan Konten Soal Asesmen Kompetensi Minimum (AKM) - Tyas Deviana, Dian Fitri Nur Aini

DOI: https://doi.org/10.31004/basicedu.v6i1.2095

dan keterampilan yang sama, namun terdapat perbedaan pada pemberdayaan pengetahuan dan keterampilan tersebut. Pemahaman keterampilan matematika tidak secara langsung menjadikan peserta didik memiliki kemampuan dan keterampilan numerasi namun hal tersebut dapat secara bertahap dilakukan (Patriana et al., 2021). Numerasi dapat diartikan sebagai kemampuan untuk mengaplikasikan konsep bilangan dan keterampilan operasi hitung dalam kehidupan sehari-hari (contextual learning), serta kemampuan untuk menginterpretasi informasi kuantitatif yang terdapat di sekitar peserta didik. Literasi numerasi bersifat praktis dan dapat digunakan dalam kehidupan sehari-hari.

Cakupan materi pada AKM lkiterasi meliputi bilangan, pengukuran dan geometri, data dan ketidakpastian, dan pengolahan data. Learning progression guru dalam mengembangkan soal AKM literasi dapat dilihat pada tabel 2 berikut ini.

Tabel 2. Learning Progression Guru Pengembangan Soal AKM Literasi Numerasi Aspek Karakteristik Materi Pembelajaran.

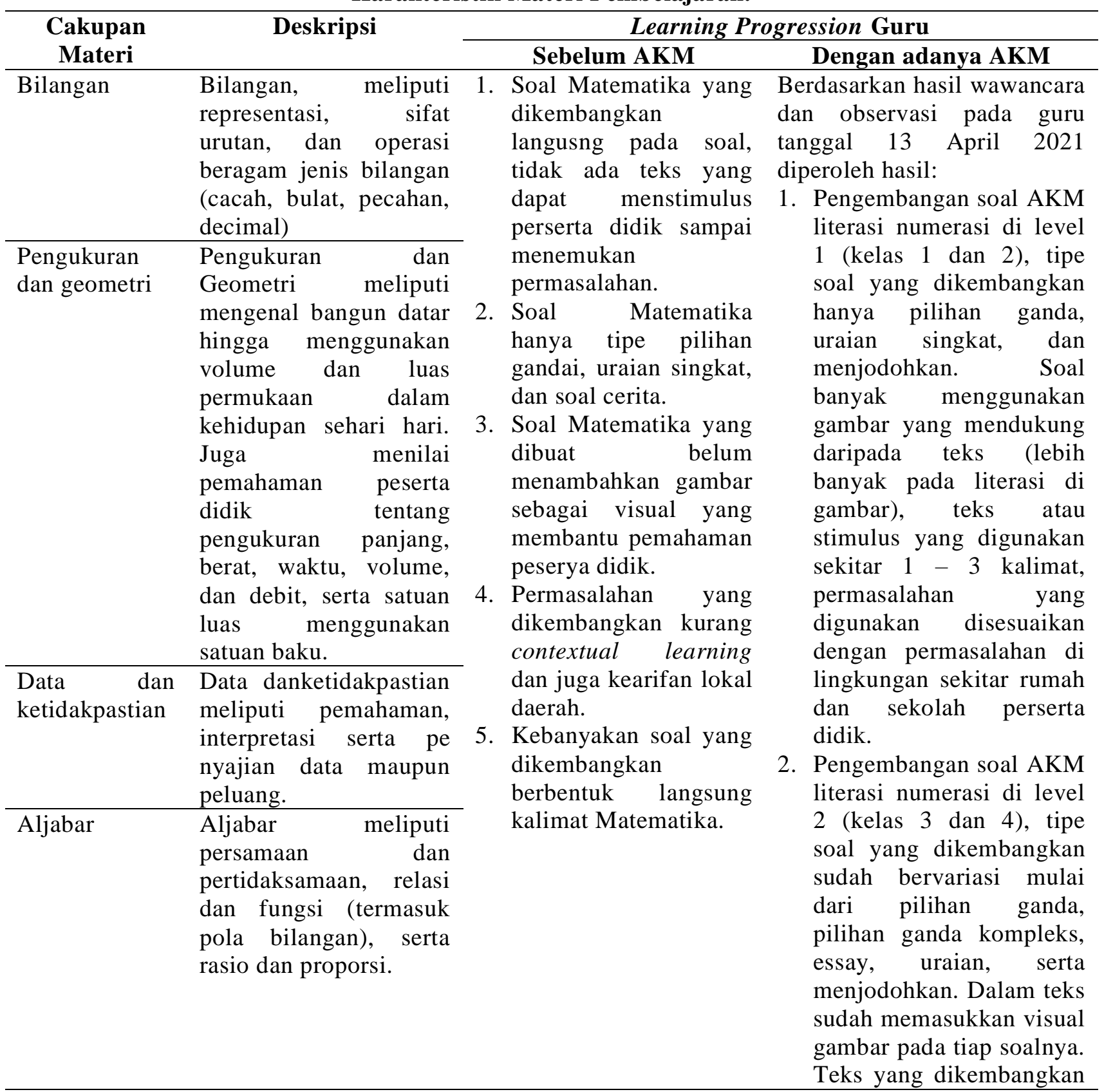


1294 Learning Progression Guru Sekolah Dasar dalam Pengembangan Konten Soal Asesmen Kompetensi Minimum (AKM) - Tyas Deviana, Dian Fitri Nur Aini

DOI: https://doi.org/10.31004/basicedu.v6i1.2095

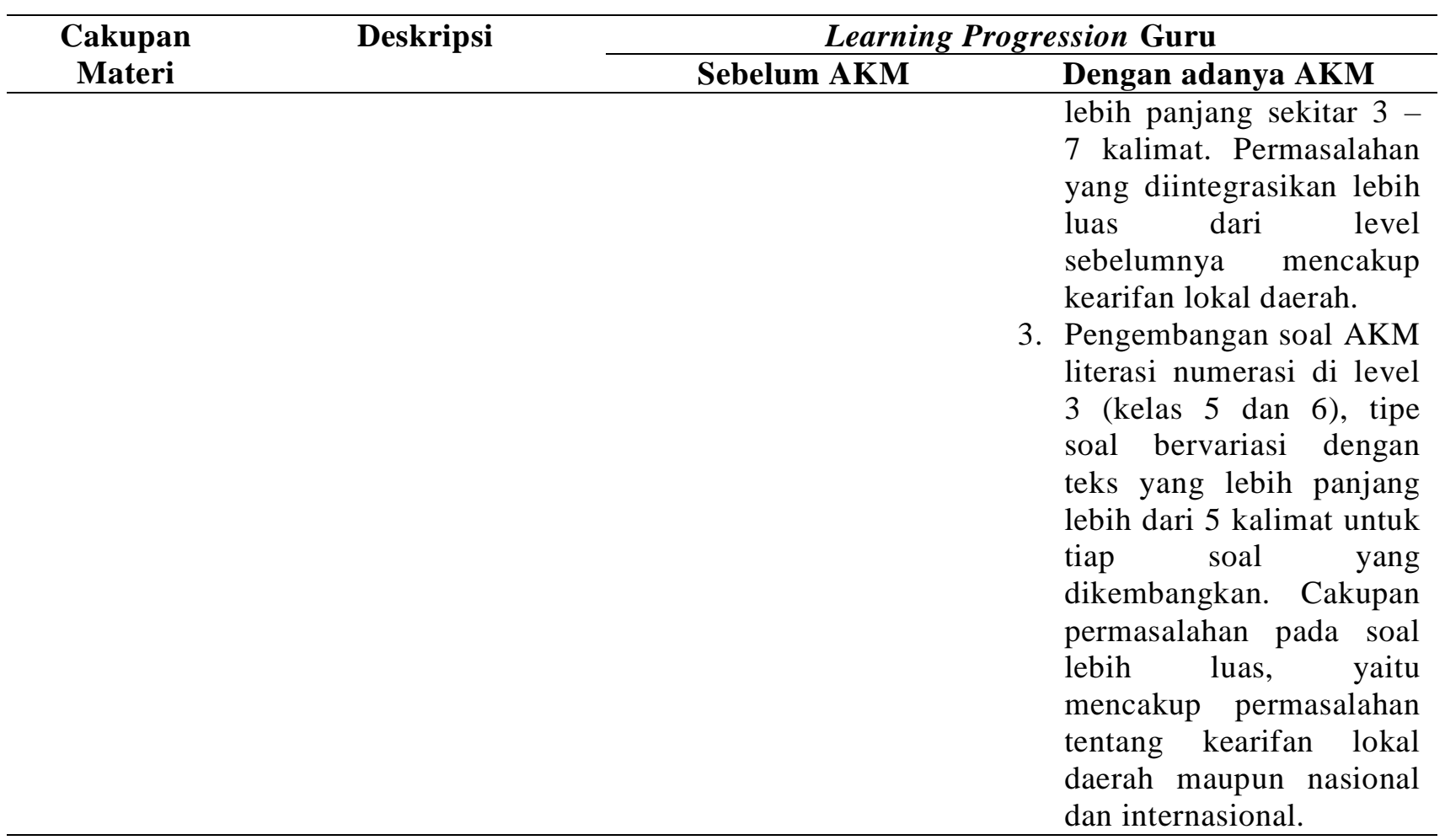

Berdasarkan analisis hasil penelitian learning progression guru dalam mengembangkan konten soal AKM literasi numerasi di jenjang SD, diketahui bahwa teks yang dikembangkan sudah sesuai dengan ketentuan AKM. AKM sola literasi numerasi yang dikembangkan pada tiap level meliputi materi bilangan, pengukuran dan geometri, data dan ketidakpastian, serta aljabar. Learning progression konten soal AKM literasi numerasi memiliki cakupan yang berjenjang sesuai dengan level dan tingkatannya (Resti et al., 2020). Cakupan level 1 meliputi permasalahan numerasi yang mencakup permasalahan di rumah dan di sekolah. Pada level 2, cakupan permasalahan lebih luas dari level 1 meliputi permasalahan di rumah, sekolah, serta kearifan lokal daerah. Dan untuk level 3 lebih luas lagi mencakup permasalahan dari lingkungan sekitar sampai pada tataran nasional dan permasalahan-permasalahan global.

\section{KESIMPULAN}

Dari hasil analisis learning progression konten soal AKM literasi membaca dan numerasi yang dikembangkan oleh guru SD, diperoleh kesimpulan bahwa soal yang dikembangkan dibuat sesuai dengan cakupan serta keluasan pada masing-masing level. Cakupan permasalahan pada level 1 mencakup permasalahan di rumah dan di sekolah, kemudian pada level 2 cakupan lebih luas lagi yaitu pada cakupan lingkungan sekitar dan kearifan lokal daerah, dan pada level 3 cakupan teks yang dikembangkan lebih luas lagi meliputi nasional dan permasalahan-permasalahan global.

Selain cakupan keluasan materi permasalahan, learning progression konten soal yang dikembangkan juga pada panjang pendek teks yang ada pada soal. Panjang teks pada soal di level 1 sekitar $3-5$ kalimat, dan bertambah panjang di level 2 sekitar 5- 7, dan untuk di level 3 bertambah panjang mencakup 7 - 9 kalimat. Tiap soal yang dikembangkan pada tiap level ditambahkan dengan visual gambar yang sesuai dengan konten.

Learning progression konten soal AKM pada jenjang SD yang sudah dikembangkan oleh guru juga terkait dengan variasi tipe soal. Variasi tipe soal pada level 1 lebih sedikit daripada level 2 maupun level 3. Variasi soal literasi membaca dan numerasi di level dua lebih banyak menggunakan pilihan ganda, uraian singkat, dan menjodohkan. Pada level 2 variasi soal meliputi pilihan ganda, uraian singkat, menjodohkan, 

Minimum (AKM) - Tyas Deviana, Dian Fitri Nur Aini

DOI: https://doi.org/10.31004/basicedu.v6i1.2095

pilihan ganda kompleks. Variasi soal lebih banyak daripada di level 1. Sedangkan untuk variasi soal di level 3 meliputi pilihan ganda, pilihan ganda kompleks, uraian, essay, dan menjodohkan.

\section{DAFTAR PUSTAKA}

Ahmad, D. N., Setyowati, L., \& Ati, A. P. (2021). Kemampuan Guru Dalam Asesmen Kompetensi Minimum ( Akm ) Untuk Mengetahui Kemampuan Literasi Dan Numerasi Peserta Didik. 58, 129-134.

Creswell, J. W., \& Poth, C. N. (2016). Qualitative Inquiry And Research Design: Choosing Among Five Approaches. Sage Publications.

Duschl, R., Maeng, S., \& Sezen, A. (2011). Learning Progressions And Teaching Sequences: A Review And Analysis. Studies In Science Education, 47(2), 123-182.

Ismail, S., \& Zakiah, Q. Y. (2021). Policy Analysis Of Implementation Of Minimum Competency Assessment As An Effort To Improve Reading Literacy Of Students In Schools. Paedagoria: Jurnal Kajian, Penelitian Dan Pengembangan Kependidikan, 12(1), 83-91.

Moleong, L. J. (2021). Metodologi Penelitian Kualitatif. Pt Remaja Rosdakarya.

Nehru, N. A. (2019). Asesmen Komptenesi Sebagai Bentuk Perubahan Ujian Nasional Pendidikan Indonesia: Analisis Dampak Dan Problem Solving Menurut Kebijakan Merdeka Belajar. Journal Of Chemical Information And Modeling, 53(9), 1689-1699.

Neumann, K., Viering, T., Boone, W. J., \& Fischer, H. E. (2013). Towards A Learning Progression Of Energy. Journal Of Research In Science Teaching, 50(2), 162-188. Https://Doi.Org/10.1002/Tea.21061

Pangesti, F. T. P. (2018). Menumbuhkembangkan Literasi Numerasi Pada Pembelajaran Matematika Dengan Soal Hots. Indonesian Digital Journal Of Mathematics And Education, 5(9), 566-575. Http://Idealmathedu.P4tkmatematika.Org

Papp, K. K., Huang, G. C., Lauzon Clabo, L. M., Delva, D., Fischer, M., Konopasek, L., Schwartzstein, R. M., \& Gusic, M. (2014). Milestones Of Critical Thinking: A Developmental Model For Medicine And Nursing. Academic Medicine, 89(5), 715-720. Https://Doi.Org/10.1097/Acm.0000000000000220

Patriana, W. D., Sutama, S., \& Wulandari, M. D. (2021). Pembudayaan Literasi Numerasi Untuk Asesmen Kompetensi Minimum Dalam Kegiatan Kurikuler Pada Sekolah Dasar Muhammadiyah. Jurnal Basicedu, 5(5), 3413-3430.

Perdana, N. S. (2021). Analysis Of Student Readiness In Facing Minimum Competency Assesment. Mukadimah: Jurnal Pendidikan, Sejarah, Dan Ilmu-Ilmu Sosial, 5(1), 15-20. Https://Jurnal.Uisu.Ac.Id/Index.Php/Mkd/Article/View/3406/2412

Plummer, J. D., \& Krajcik, J. (2010). Building A Learning Progression For Celestial Motion: Elementary Levels From An Earth-Based Perspective. Journal Of Research In Science Teaching, 47(7), 768-787. Https://Doi.Org/10.1002/Tea.20355

Rahmayanti, N., \& Affandi, M. (2021). Analisis Tingkat Kognitif Soal Pendidikan Agama Islam Tingkat Sma Berbasis Assesmen Kompetensi Minimum. Al-Fikri: Jurnal Studi Dan Penelitian Pendidikan Islam, 4(1), 82-95.

Resti, Y., Zulkarnain, Z., Astuti, A., \& Kresnawati, E. S. (2020). Peningkatan Kemampuan Numerasi Melalui Pelatihan Dalam Bentuk Tes Untuk Asesmen Kompetensi Minimum Bagi Guru Sdit Auladi Sebrang Ulu Ii Palembang. Applicable Innovation Of Engineering And Science Research (Avoer), 670-673.

Sani, R. A. (2021). Pembelajaran Berorientasi Akm: Asesmen Kompetensi Minimum. Bumi Aksara.

Sari, D. R., Lukman, E. N., \& Muharram, M. R. W. (2021). Analisis Kemampuan Siswa Sd Dalam Menyelesaikan Soal Geometri Asesmen Kompetensi Minimum. Jpg: Jurnal Pendidikan Guru, 2(4), 186-190. 
1296 Learning Progression Guru Sekolah Dasar dalam Pengembangan Konten Soal Asesmen Kompetensi Minimum (AKM) - Tyas Deviana, Dian Fitri Nur Aini

DOI: https://doi.org/10.31004/basicedu.v6i1.2095

Sevian, H., \& Talanquer, V. (2014). Rethinking Chemistry: A Learning Progression On Chemical Thinking. Chemistry Education Research And Practice, 15(1), 10-23.

Sofanudin, A. (2020). Literasi, Numerasi Dan Survei Karakter.

Stevens, S. Y., Shin, N., \& Peek-Brown, D. (2013). Learning Progressions As A Guide For Developing Meaningful Science Learning: A New Framework For Old Ideas. Educación Química, 24(4), 381-390.

Tohir, M. (2019). Empat Pokok Kebijakan Merdeka Belajar. Https://Doi.Org/10.31219/Osf.Io/67rcq

Wilson, M. (2009). Measuring Progressions: Assessment Structures Underlying A Learning Progression. Journal Of Research In Science Teaching, 46(6), 716-730. Https://Doi.Org/10.1002/Tea.20318 